\title{
Pranayama dalam Prenatal Yoga
}

\author{
I Putu Suyoga Hindhuyana ${ }^{1}$, Putu Ayu Sri Kumala Dewi \\ ${ }^{1}$ Sekretariat Daerah Kabupaten Badung \\ ${ }^{2}$ Direktorat Jenderal Bimbingan Masyarakat Hindu \\ e-mail: suyogahindhuyana1@gmail.com ${ }^{1}$, srikumaladewi1@gmail.com²
}

Diterima tanggal 30 Juli 2021, diseleksi tanggal 12 Agustus 2021, dan disetujui tanggal 29 Agustus 2021

\begin{abstract}
Pregnancy is an event that occurs in women which generally gives various changes in themselves. Along with the development of the fetus and increasing gestational age, a woman will certainly experience several changes such as physical changes, psychological changes, and social status of the mother. The changes that occur during pregnancy generally occur as symptoms and occur for most pregnant women. Either with, arise, or fear that is in itself, especially in pregnant women, one of the prenatal yoga exercises can be effectively overcome by doing pranayama exercises. During pregnancy, the body's needs are certainly different from the bodies of people who have never experienced the process of pregnancy. Likewise, with the need for pranayama exercises performed during pregnancy, which of course not all pranayama techniques can be practiced during pregnancy. There are several pranayama techniques that are good to practice during pregnancy, namely diaphragmatic breathing techniques, dirgha swasam breathing techniques, sitkari pranayama, sitali pranayama, bhramari pranayama, ujjayi pranayama, and anuloma viloma pranayama.
\end{abstract}

Keywords: pranayama; prenatal; yoga

\begin{abstract}
ABSTRAK
Kehamilan ialah sebuah keajaiban yang terjadi pada perempuan yang pada umumnya memberikan berbagai jenis perubahan pada diri. Seiring dengan berkembangnya janin serta bertambahnya usia kehamilan, seorang perempuan tentunya akan mengalami beberapa perubahan fisiologis seperti perubahan fisik, perubahan psikis, dan status sosial pada ibu. Perubahanperubahan yang terjadi selama kehamilan umumnya menimbulkan ketidaknyamanan dan kekhawatiran bagi sebagian besar ibu hamil. Baik kecemasan, kekhawatiran, maupun rasa takut yang timbul dari dalam diri khususnya pada wanita hamil dapat diatasi secara efektif dengan salah satu teknik latihan prenatal yoga yaitu dengan melakukan latihan pranayama. Pada masa kehamilan, kebutuhan tubuh tentu berbeda dengan tubuh orang yang tidak mengalami proses kehamilan. Begitu pula dengan kebutuhan latihan pranayama yang dilakukan pada saat kehamilan, tentunya tidak semua teknik pranayama dapat dipraktikkan pada masa kehamilan. Terdapat beberapa teknik pranayama yang baik dipraktikkan selama masa kehamilan yaitu teknik pernapasan diafragma, teknik pernapasan dirgha swasam, sitkari pranayama, sitali pranayama, bhramari pranayama, ujjayi pranayama, dan anuloma viloma pranayama.
\end{abstract}

Kata kunci: pranayama; prenatal; yoga 


\section{PENDAHULUAN}

Kehamilan merupakan sebuah keajaiban yang terjadi pada perempuan yang pada umumnya memberikan berbagai perubahan pada diri. Seiring dengan berkembangnya janin serta bertambahnya usia kehamilan, seorang perempuan tentunya akan mengalami beberapa perubahan fisiologis seperti perubahan fisik, perubahan psikis, dan status sosial pada ibu.

Proses kehamilan merupakan satu kesatuan mata rantai mulai dari konsepsi, nidasi, adaptasi ibu terhadap nidasi, pemeliharaan kehamilan, perubahan hormon sebagai persiapan menyongsong kelahiran bayi. Segala perubahan fisik dialami wanita selama hamil berhubungan dengan beberapa sistem yang disebabakan oleh efek khusus dari hormon (Yeyeh, 2014). Perubahan ini terjadi dalam rangka persiapan perkembangan janin, menyiapkan tubuh ibu untuk bersalin, perkembangan payudara untuk pembentukan atau produksi air susu ibu selama masa nifas. Wanita selama kehamilannya memerlukan waktu untuk beradaptasi dengan berbagai perubahan yang terjadi dalam dirinya. Perubahan pada ukuran tubuh, bentuk payudara, pigmentasi kulit, serta pembesaran abdomen secara keseluruhan membuat tubuh ibu hamil tampak jelek sehingga menimbulkan rasa tidak percaya diri pada ibu hamil tersebut.

Perubahan-perubahan yang terjadi selama kehamilan umumnya menimbulkan ketidaknyamanan dan kekhawatiran bagi sebagian besar ibu hamil. Kekhawatiran dan ketakutan yang sering terjadi pada ibu hamil dapat membawa ibu hamil menjadi tidak siap dalam menghadapi kehamilannya sehingga memungkinkan untuk terjadinya kehamilan yang bermasalah yang ditandai dengan munculnya tanda-tanda bahaya kehamilan yang dapat berakhir dengan kematian (Kusmiaty dkk, 2009).

Kekhawatiran maupun ketakutan yang umum terjadi pada ibu hamil sebenarnya tidak berdasar, karena sebagian besar ibu hamil tidak sepenuhnya memahami perubahan yang terjadi. Hal ini dipengaruhi oleh beberapa faktor yaitu usia, pendidikan, pekerjaan dan sumber informasi. Oleh karena itu ibu hamil membutuhkan penjelasan, arahan dan saran tentang perubahan selama kehamilan baik dari bidan, tenaga perawat dan dokter, agar ibu hamil tidak mengkhawatirkan suatu kondisi perubahan yang terjadi.

Selaras dengan yang dinyatakan oleh (Ismayana, 2017) bahwa apabila ibu hamil sudah mengerti tentang perubahan fisiologis yang terjadi pada masa kehamilan maka rasa takut dan cemas selama hamil dapat dihindari dan apabila terdapat suatu kelainan pada kehamilan, ibu akan mengerti dan segera memeriksakan diri ke petugas kesehatan, sebaliknya jika ibu hamil tidak mengerti akan perubahan fisiologis yang terjadi pada masa kehamilan seorang ibu akan merasa cemas dan takut akan perubahan yang terjadi pada tubuhnya selama hamil. 
Baik kecemasan, kekhawatiran, maupun rasa takut yang timbul dari dalam diri khususnya pada wanita hamil dapat diatasi secara efektif dengan salah satu teknik latihan prenatal yoga yaitu dengan melakukan latihan pranayama. Pada masa kehamilan, kebutuhan tubuh tentu berbeda dengan tubuh orang yang tidak mengalami proses kehamilan. Begitu pula dengan kebutuhan latihan pranayama yang dilakukan pada saat kehamilan, yang tentunya tidak semua teknik pranayama dapat dipraktikkan pada masa kehamilan. Pada artikel ini akan dimuat beberapa teknik latihan pranayama yang dapat dilakukan oleh seseorang dalam masa kehamilan untuk meningkatkan rasa percaya diri serta meningkatkan kesiapan diri dalam proses melahirkan hingga menjadi seorang ibu.

Penulisan artikel ini menggunakan pendekatan kualitatif dengan menerapkan metode deskriptif analitis. Data dikumpulkan dengan teknik studi literature dengan mencari database dari berbagai referensi, seperti jurnal penelitian, review jurnal, annual report, buku dan data-data yang berkaitan dengan prenatal yoga, kecemasan, kehamilan dan persalinan yang diterbitkan pada tahun 2005-2021. Pencarian literature dilakukan dengan menggunakan mesin pencari google di internet dengan kata kunci: prenatal yoga, kecemasan, kehamilan dan persalinan. Database yang diambil dari artikel yang dipublikasikan pada Google Schoolar, PubMed dan Researchgate.

\section{PEMBAHASAN}

\subsection{Definisi Prenatal Yoga}

Istilah yoga tentunya sudah tidak asing lagi bagi masyarakat Hindu, namun pemahaman masyarakat tentang arti istilah yoga secara keseluruhan tidak sama. Berbagai macam makna yoga muncul di masyarakat, namun untuk mendapatkan esensi, pemahaman dan makna dari istilah yoga, diperlukan penelusuran yang mendalam tentang asal usul istilah tersebut.

Menurut Maha Rsi Patanjali dalam kitab Yoga Sutra (Saraswatī, 2005), istilah yoga dirangkum dalam sebuah kalimat pendek atau sutra sebagai berikut: "Yogas Citta Vrtti Nirodhah" (Yoga Sutra I.2) artinya: yoga adalah pengekangan benih-benih pikiran (citta) dari pengambilan berbagai wujud (perubahan; wrtti). (Zuhrotunida, 2020) menjelaskan bahwa yoga menciptakan keseimbangan antara emosional, mental, fisik dan dimensi spiritual. Yoga merupakan suatu sistem yang komprehensif antara fisik (asana), latihan pernafasan (pranayama), konsentrasi dan meditasi (dharana dan dhyana) dan kontemplatif praktek.

Sedangkan kata "prenatal" dalam kamus besar bahasa Indonesia online diartikan sebagai suatu kondisi yang bersangkutan dengan hal atau keadaan sebelum melahirkan (https://kbbi.web.id/prenatal). (Mujahidin , A. \& Khoiriyah, 2018) menjelaskan bahwa "pra" 
artinya sebelum, "natal" artinya lahir. Masa prenatal yaitu periode perkembangan manusia yang dimulai dari pembuahan sperma dan ovum sampai masa kelahiran.

Usia kehamilan normal dan sehat selama 280 hari atau 40 minggu, dan dapat di bagi menjadi tiga trimester (Wardani, 2012).

a. Trimester I

Kehamilan trimester pertama adalah keadaan mengandung embrio atau fetus didalam tubuh 0 -14 minggu.

\section{b. Trimester II}

Kehamilan trimester kedua adalah mengandung embrio atau fetus dalam tubuh 14- 28 minggu.

c. Trimester III Trimester ketiga adalah keadaan mengandung embrio atau fetus di dalam tubuh pada 28 - 40 minggu.

Prenatal yoga atau yoga hamil atau sering pula disebut dengan antenatal yoga kini menjadi trend bagi para ibu yang sedang mengalami masa kehamilan. Menurut (Rusmita, 2015), istilah prenatal yoga merupakan kombinasi gerakan senam hamil dengan gerakan yoga antenatal yang terdiri dari gerakan penafasan (pranayama), posisi (mudra), meditasi dan relaksasi yang dapat membantu kelancaran dalam kehamilan dan persalinan.

Menurut (Rafika, 2018), prenatal yoga (yoga selama kehamilan) merupakan salah satu jenis modifikasi dari hatha yoga yang disesuaikan dengan kondisi ibu hamil. Tujuan prenatal yoga adalah mempersiapkan ibu hamil secara fisik, mental dan spiritual untuk proses persalinan. Hal ini juga selaras dengan yang dinyatakan oleh (Wulandari \& Wantini, 2021) bahwa yoga antenatal merupakan keterampilan mengolah pikiran, berupa teknik pengembangan kepribadian secara menyeluruh baik fisik, psikologis dan spiritual.

Sesuai dengan teori (Sindhu, 2009), bahwa dengan berlatih yoga pada masa kehamilan merupakan salah satu soluasi yang bermanfaat sebagai media self help yang akan mengurangi ketidaknyamanan selama masa hamil, membantu proses persalinan, dan bahkan mempersiapkan mental untuk masa-masa awal setelah melahirkan dan saat membesarkan anak. Ibu hamil yang berolahraga secara teratur, tingkat laporan mengalami ketidaknyamanan selama kehamilan lebih rendah dan penyembuhan lebih cepat daripada yang tidak berolahraga selama kehamilan.

Sependapat dengan teori dan hasil penelitian yang dikemukakan oleh (Stoppard, 2008); (Beddoe \& Lee, 2008); (Sindhu, 2009) dan (Wiadnyana, 2011) bahwa manfaat latihan yoga bagi ibu hamil, bersalin dan nifas yaitu dapat meringankan edema dan kram yang sering terjadi pada bulan-bulan terakhir kehamilan, membantu posisi bayi dan pergerakan, meningkatkan sistem pencernaan dan nafsu makan, meningkatkan energi dan memperlambat metabolisme untuk 
memulihkan ketenangan dan fokus, mengurangi rasa mual, morning sickness dan suasana hati, meredakan ketegangan di sekitar leher rahim dan jalan lahir, yang berfokus pada membuka pelvis untuk mempermudah persalinan, membantu dalam perawatan pasca kelahiran dengan mengembalikan uterus, perut dan dasar panggul, mengurangi ketegangan, cemas dan depresi selama hamil, persalinan nifas dan ketidaknyamanan payudara.

Sehingga dari penjelasan beberapa pakar mengenai prenatal yoga dapat ditarik benang merah bahwa dalam artikel ini yang dimaksudkan dengan prenatal yoga yaitu aktivitas yoga yang dilakukan dengan teknik-teknik tertentu oleh wanita hamil dengan tujuan memperlancar proses pada saat masa kehamilan hingga menghadapi waktu persalinan atau melahirkan. Praktik yoga yang dilakukan pada masa kehamilan juga harus diperhatikan karena kebutuhan setiap wanita hamil tentu berbeda sesuai dengan kondisi calon ibu dan juga janin. Oleh karena itu perlu diperhatikan jenis praktik yoga yang dapat dilakukan oleh wanita hamil.

\subsection{Pranayama dalam Prenatal Yoga}

Praktik yoga sesungguhnya adalah kesatuan antara olah tubuh, pikiran, dan nafas yang sangat kompleks. Praktik yoga yang dikenal oleh masyarakat pada umumnya kebanyakan dalam bentuk oleh fisik yang disebut asanas. Hal itu tidaklah salah, karena asanas adalah bagian dari yoga itu sendiri. Sejatinya, praktik yoga tidak hanya mengacu pada olah tubuh semata, melainkan suatu praktik latihan yang dilakukan dengan kesatuan yang holistic.

Maha Rsi Pātañjali memberikan penjelasan tentang konsep yoga, dari tiap-tiap tahapan konsep yoga itu yang disebut dengan Astangga Yoga, yakni yoga dengan delapan tahapan. Kedelapan tahapan tersebut dalam yogasutra II. 29 disebutkan yama, niyamāsana, prānāyāmapratyāhāra dhāranadhyāna samādhi yo stavanggani. Pengekangan diri (yama), kepatuhan yang mantap (niyama) sikap badan (āsana), pengaturan nafas (prānāyāma) penyaluran (pratyahara), pemusatan ataukonsentrasi (dhārana), perenungan (dhyāna), dan penyerapan (Samādhi), semua ini merupakan bagian dari disiplin yoga (Madja, 2018).

Berdasarkan untaian dari yogasutra tersebut dapat dikatakan bahwa praktik yoga sesungguhnya sangat kompleks. Namun, praktik yoga yang paling sering dijumpai pada tempat latihan atau studio-studio yoga adalah praktik asana, pranayama, serta meditasi. Praktik yoga dalam prenatal yoga juga sedemikian kompleks sehingga sangat dianjurkan dilakukan oleh wanita hamil. Namun, praktik yoga yang dipraktikkan dalam kelas prenatal yoga tentunya berbeda dengan praktik yoga pada umumnya. Praktik yoga pada prenatal yoga lebih menitik beratkan pada latihan 
pernafasan guna memantapkan diri pada masa kehamilan serta mempersiapkan diri dalam menghadapi persalinan atau proses saat melahirkan.

Senada dengan yang disampaikan oleh (Aprilia, 2015) bahwa bagi para pemula, disarankan untuk melakukan senam yoga yang berbasis pada teknik pranayama yoga. Gerakan dalam senam yoga sangat bervariasi, mulai dari yang sederhana hingga yang rumit. Oleh karena itu, pengertian senam yoga juga termasuk melakukan teknik yoga dengan prinsip sweet discomfort, di mana seorang pelaku yoga sebaiknya tidak memaksakan suatu gerakan di luar kemampuan dan kebutuhannya. Artikel ini akan khusus membahas mengenai pranayama (pengaturan nafas) dalam praktik prenatal yoga yang penulis sampaikan berdasarkan atas hasil-hasil penelitian serta kajiankajian kritis akademisi serta praktisi yang membidangi prenatal yoga.

Yoga pranayama merupakan unsur terpenting dalam melakukan yoga. Teknik pernafasan dalam Yoga Prayanama memberikan asupan oksigen lebih banyak pada ibu hamil dan janinnya dan sistem saraf parasimpatis menjadi rileks (Beddoe \& Lee, 2008).

Curtis dalam (Sophia et al., 2018) menyatakan bahwa latihan relaksasi pernafasan akan membalikkan efek stres yang melibatkan bagian parasimpatik dari sistem syaraf pusat. Relaksasi akan menghambat peningkatan syaraf simpatik, sehingga hormon penyebab disregulasi tubuh dapat dikurangi jumlahnya. Sistem syaraf parasimpatetik, yang memiliki fungsi kerja yang berlawanan dengan syaraf simpatik, akan memperlambat atau memperlemah kerja alat-alat internal tubuh. Akibatnya, terjadi penurunan detak jantung, irama nafas, tekanan darah, ketegangan otot, tingkat metabolisme, dan produksi hormon penyebab stres. Seiring dengan penurunan tingkat hormon penyebab stres, maka seluruh badan mulai berfungsi pada tingkat lebih sehat. Dengan demikian, ibu hamil akan merasa rileks seiring dengan menurunnya gejala kecemasan.

Bara (2021) pada penelitiannya mengenai prenatal yoga menyampaikan bahwa prenatal yoga diikuti oleh ibu hamil mulai trimester 2, dilakukan setiap selasa dan jumat selama 90 menit. Setiap sesi dimulai dari latihan pranayama (pernafasan), latihan asana dan kegel. Pada bagian akhir dilakukan latihan relaksasi dan afrmasi positif. Hasil yang dapat disimpulkan dari kegiatan ini adalah meningkatnya kebugaran fisik ibu hamil dan meningkatkan kesiapan psikologis hamil.

Zuhrotunida (2020) dalam jurnal ilmiahnya yang berjudul "Efektifitas Yoga Terhadap Tingkat Kecemasan Ibu Bersalin: Studi Literatur" menyatakan bahwasanya dengan latihan pernafasan yang dilakukan selama yoga, ibu akan terbiasa melakukan nafas pendek dan cepat dengan ritme yang teratur serta panjang dan dalam baik saat menghirup maupun melepaskan udara. Pelatihan nafas bisa menenangkan calon ibu untuk melalui rasa sakit dalam proses persalinan, serta memicu sistem saraf yang memperlancar pembukaan dan peregangan dinding vagina. 
Sophia et al (2018) menyatakan bahwa yoga pranayama merupakan unsur terpenting dalam yoga yang melatih teknik pernafasan. Teknik pernafasan dalam yoga prayanama memberikan asupan oksigen lebih banyak pada ibu hamil dan janin, menurunkan efek stres yang melibatkan saraf parasimpati sehingga ibu hamil menjadi rileks. Hasil penelitiannya menunjukkan adanya penurunan tingkat kecemasan ibu hamil Timester III sebelum dan setelah dilakukan Yoga Pranayama $(\mathrm{p}=0,00)$.

Berdasarkan hasil analisis jurnal penelitian di atas maka dapat disimpulkan bahwa pranayama memiliki manfaat yang baik dan penting untuk dipraktikkan oleh wanita selama masa kehamilan berlangsung. Berbagai dampak positif juga akan diperoleh apabila melakukan praktik pranayama dengan teknik yang tepat derta dilakukan secara rutin.

\subsection{Teknik Pranayama dalam Prenatal Yoga}

Pelatihan yoga untuk kehamilan atau prenatal yoga khususnya teknik pranayama sangat dianjurkan bagi wanita hamil. Pernapasan menjembatani komunikasi antara ibu dan janinnya dan bertindak sebagai mediator pengendalian diri untuk menjaga kesadaran pada saat melahirkan dan meremajakan energi tubuh, oleh sebab itu praktik pranayama pada wanita hamil tidak dianjurkan melakukan kumbhaka (menahan napas) agar tidak menghentikan aliran oksigen ke janin. Singkatnya, teknik pernapasan yoga dapat digunakan untuk menjaga keseimbangan aktivitas mental dan membantu mengurangi ketidaknyamanan selama kehamilan.

Berikut ini akan penulis sampaikan beberapa teknik pranayama yang dapat dipraktikkan selama masa kehamilan sesuai dengan hasil analisis terhadap berbagai jurnal penelitian ilmiah yang ditemukan oleh penulis.

\subsubsection{Teknik Pernapasan Diafragma}

Teknik pernapasan ini merupakan teknik pernapasan dasar dari semua teknik pernapasan yoga (pranayama). Teknik pernapasan diafragma bermanfaat untuk mengaktifkan otot diafragma dan paru-paru bagian bawah, memijat organ perut bagian dalam, melancarkan pencernaan/mengatasi sembelit, melatih kesadaran pada otot-otot dasar panggul, serta meningkatkan ketenangan. Teknik pernapasan diafragma juga merupakan teknik pernapasan yang digunakan saat bermeditasi.

Menurut Sindhu (2009) teknik pernapasan ini dapat dilakukan sejak masa awal kehamilan. Dilakukan sambil duduk dengan nyaman di atas bantal tipis dengan posisi pinggul yang lebih tinggi dari lutut dan punggung tegak, atau dengan melakukannya sambil duduk bersandar nyaman pada bantal tebal (puff) atau sofa. Untuk yang berada pada trimester awal (1-3 bulan) dapat 
melakukan teknik pernapasan ini sambil dalam posisi berbaring dengan kedua lutut ditekuk dan disangga dengan menggunakan bantal.

Dari buku yang ditulis oleh Sindhu (2009) dan hasil penelitian dari Resmaniasih (2014) terkait cara melakukan pernapasan diafragma, terdapat beberapa teknik dalam melakukan pernapasan diafragma yang efektif dipraktikkan pada prenatal yoga, yaitu sebagai berikut.

1. Teknik I

a. Letakkan kedua tangan di perut bagian atasm pada lengkungan atas perut.

b. Tarik napas melalui hidung, dan rasakan perut bagian atas mengembang lembut sehingga mendorong tangan ke luar.

c. Saat melakukan ini, jaga agar dada dan bahu tetap diam.

d. Buang napas, rasakan perut kembali lembut mengempis.

e. Lakukan selama beberapa putaran tanpa menahan napas dan lakukan sambil memejamkan mata agar merasa lebih nyaman.

2. Teknik II

a. Letakkan kedua tangan di perut bagian bawah, pada lengkungan bawah perut.

b. Tarik napas melalui hidung, dan rasakan perut bagian bawah mengembang sehingga mendorong tangan ke luar.

c. Buang napas, rasakan perut kembali lembut mengempis.

d. Lakukan selama beberapa putaran dan dapat dilakukan sambil memejamkan mata.

3. Teknik III

a. Letakkan satu tangan pada perut bagian atas, dan tangan lainnya pada perut bagian bawah.

b. Tarik napas melalui hidung, rasakan perut mengembang, dan jarak di antara kedua tangan semakin merenggang.

c. Buang napas, rasakan perut kembali melembut mengempis, dan jarak di antara kedua tangan kembali seperti semula.

d. Lakukan selama beberapa putaran sembari memejamkan mata.

2.3.2 Teknik Pernapasan Dirgha Swasam

Teknik pernapasan ini merupakan lanjutan dari teknik pernapasan diafragma. Pernapasan Dirgha swasam pranayama memberikan manfaat optimal dari proses pernapasan. Dengan kata lain, mengoptimalkan kemampuan paru-paru untuk menarik oksigen dan meningkatkan jumlah oksigen dan prana yang diserap oleh tubuh, memberikan lebih banyak oksigen dan prana ke janin dan memberikan relaksasi yang lebih lengkap serta melatih otot jantung dan paru-paru. Teknik dalam melakukan dirgha swasam pranayama, yaitu sebagai berikut. 
a. Duduk dengan posisi tegak, kemudian letakkan kedua tangan dengan santai di atas lutut, atau letakkan satu tangan di atas tulang dada dan satu tangan pada perut bagian bawah. Lakukan beberapa kali putaran teknik pernapasan diafragma terlebih dahulu.

b. Selanjutnya, tarik napas yang mendalam melalui kedua lubang hidung, kemudian rasakan perut mengembang terlebih dahulu dan mendorong tangan ke arah luar, setelah itu rasakan dada mengembang, dan terakhir kedua bahu sedikit terangkat.

c. Buang napas, rasakan perlahan bahu kembali ke posisi awal, dada mengempis, dan perut kembali perlahan mengempis.

d. Lakukan teknik pernapasan ini dengan rasio 1:1 (satu waktu tarikan napas berbanding satu waktu hembusan napas) selama beberapa putaran dan dilakukan sambil memejamkan mata.

\subsubsection{Sitkari Pranayama (Teknik Pernapasan Gigi)}

Teknik pernapasan ini dilakukan dengan dasar teknik pernapasan diafragma atau dirgha swasam, dan bermanfaat untuk memberikan kesejukan pada tubuh, menenangkan pikiran, meringankan heartburn (nyeri ulu hati), mengatasi panas dalam dan meringankan rasa mual. Dapat dilakukan dalam posisi tubuh manapun (duduk, berdiri, berbaring). Dilakukan di tempat yang bersih dari polusi udara. Teknik melakukan sitkari pranayama yaitu sebagai berikut.

a. Tempelkan gigi bagian atas dan bawah, tempelkan ujung lidah pada titik pertemuan gigi.

b. Tarik napas melalui mulut/gigi, dan rasakan udara sejuk memasuki rongga mulut, tenggorokan, dan rongga dada. Tutup mulut selesai menarik napas.

c. Buang napas, perlahan keluarkan napas melalui lubang hidung. Step ini dilakukan selama beberapa putaran napas.

\subsubsection{Sitali Pranayama (Teknik Pernapasan Lidah)}

Sitali pranayama juga pada dasarnya menggunakan teknik pernapasan diafragma atau dirgha swasam. Sitali pranayama dilakukan melalui lidah yang digulung seperti pipa/sedotan. Manfaatnya sama dengan Sitkari Pranayama. Apabila tidak bisa melakukan menggulung lidah (biasanya factor genetis seseorang), dapat melakukan sitkari pranayama. Cara melakukan sitali pranayama sebagai berikut.

a. Gulung lidah hingga membentuk pipa/sedotan.

b. Tarik napas melalui rongga lidah tersebut, dan rasakan udara sejuk memasuki rongga mulut, tenggorokan, dan dada. Tutup mulut selesai menarik napas dan kembalikan lidah ke posisi normal.

c. Buang napas melalui lubang hidung. Lakukan beberapa putaran napas selama 2-5 menit.

d. Setelah itu, minum air putih sebanyak-banyaknya. 


\subsubsection{Bhramari Pranayama (Teknik Pernapasan Berdengung)}

Bhramari pranayama dilakukan dengan dasar pernapasan diafragma atau dapat juga dengan dirgha swasam. Bhramari disebut juga sebagai teknik pernapasan lebah (bee breath) karena saat menghembuskan napas akan keluar suara mendengung panjang seperti dengungan lebah. Teknik pernapasan ini bermanfaat untuk mengusir kecemasan, menenangkan pikiran, dan mengatasi insomnia (sulit tidur).

Maharani (2020) menyatakan bahwasanya bhramari pranayama ini bermanfaat untuk menenangkan pikiran pada saat ada masalah mendadak. Pranayama ini juga membuat wajah menjadi bercahaya, pikiran menjadi kuat, jauh dari penyakit telinga. Bahkan para yogi yang melakukan Bhramari Pranayama akan mengetahui Anahatnada (suara bathin) dan mengetahui kematiannya.

Bhramari pranayama diawali dilakukan dengan sikap duduk bersila di atas bantal tipis dengan posisi panggul lebih tinggi daripada lutut dnegan punggung tegak. Sumbat kedua lubang telinga dengan ibu jari tangan, telunjuk menutup alis, jari tengah dan jari manis menutup mata dengan lembut, kelingking sedikit menekan bagian tulang hidung, dengan teknik sebagai berikut.

a. Tempatkan jari-jari tangan untuk menutuk telinga dan mata.

b. Kemudian lakukan penarikan napas secara mendalam dari kedua lubang hidung, dan sempitkan pita suara di ujung tarikan napas.

c. Satukan gigi atas dan gigi bawah kemudian buang napas perlahan dan panjang. Istirahatkan pikiran dengan mendengarkan suara mendengung panjang yang dihasilkan saat melakukan posisi ini.

d. Pranayama ini dilakukan selama beberapa kali putaran tarikan dan hembusan napas tanpa menahan napas hingga merasa nyaman.

\subsubsection{Ujjayi Pranayama}

Ujjayi pranayama disebut juga sebagai pernapasan lautan atau pernapasan kobra. Ujjayi pranayama adalah napas diafragma yang inhalasi dan pernapasan keduanya dilakukan melalui suara hidung (suara lautan). Diciptakan dengan menggerakkan glotis (lubang/celah yang menghubungkan faring dengan trakea) ketika udara masuk dan keluar. (Sena, 2020)

Berdasarkan analisis penulis dari jurnal penelitian (Sena, 2020) dan (Rahmawati, 2020), dapat dipaparkan teknik dalam melakukan ujjayi pranayama yaitu sebagai berikut.

a. Diawali dengan mengambil sikap duduk yang nyaman.

b. Kemudian celah suara dalam tenggorakan dikontraksikan, selanjutnya lakukan kechari mudra (lipat lidah bagian belakang, hingga sisi bawah lidah ditekan pada belakang langit-langit mulut bagian atas). 
c. Tarik napas dalam-dalam dan lembut melalui rongga kerongkongan, rasakan napas masuk secara mendalam hingga ke jantung seperti dengkuran bayi yang sedang tidur atau suara lautan. Rasakan bahwa napas yang dilakukan berasal dari kerongkongan.

d. Hembuskan napas secara perlahan melalui kerongkongan, dapat dilakukan dengan disertai memejamkan mata.

\subsubsection{Anuloma Viloma Pranayama}

Teknik pernapasan ini dilakukan dengan dasar teknik pernapadan diafragma atau dapat juga dilakukan dengan dasar teknik pernapasan dirgha swasam, dan dilakukan secara bergantian antara lubang hidung kanan dan kiri. Bermanfaat untuk menyeimbangkan aktivitas pikiran, menghilangkan kecemasan dan menenangkan pikiran ibu hamil, serta meningkatkan konsentrasi dan keseimbangan tubuh dan pikiran.

Selaras dengan yang dinyatakan oleh (Maharani, 2020) bahwa Anulom Vilom Pranayama dapat menyeimbangkan tekanan darah, baik tinggi atau rendah, melancarkan peredaran darah, susah tidur, paru-paru basah, cemas, takut, sakit kepala, migren dan vertigo.

Saat melakukan Anuloma Viloma Pranayama, buat postur tangan mudra Wisnu dan letakkan di dada. Pertama lakukan beberapa siklus pernapasan Dirgha Svasam, lalu lakukan teknik Anuloma Viloma sebagai berikut.

a. Tarik napas melalui kedua lubang hidung.

b. Buang napas, kososngkan paru-paru, dan tekan lubang hidung kanan dengan ibu jari tangan kanan.

c. Tarik napas dari lubang hidung kiri selama 5 detik, kemudian di ujung tarikan napas, tekan dan tutup lubang hidung kiri dengan jari manis dan kelingking.

d. Buang napas, buka ibu jari dan keluarkan napaa dari lubang hidung kanan selama 5 atau 10 detik.

e. Tarik napas dari lubang hidung kanan selama 5 detik. Tekan dan tutup lubang hidung kanan di ujung tarikan napas. Buang napas, lepaskan napas melalui lubang hidung kiri.

f. Lakukan teknik pernapasan ini selama 3-6 putaran.

Secara klasik, teknik pernapasan ini dilakukan dengan menambahkan kumbhaka (menahan napas) di akhir tarikan napas. Karena ibu hamil tidak diperbolehkan menahan napas, teknik anuloma viloma pranayama bagi ibu hamil dilakukan tanpa proses kumbhaka. Lakukan sambil duduk bersila di atas bantal tipis dengan posisi pinggul yang lebih tinggi daripada lutut dengan punggung tegak, atau lakukan sambil duduk bersandar nyaman pada bantal tebal (puff) atau sofa. Lakukan teknik ini dengan rasio 1:2 (satu waktu tarikan napas berbanding dua waktu hembusan napas) atau 1:1. 


\section{PENUTUP}

Berdasarkan pemaparan mengenai pranayama dalam prenatal yoga, dapat disimpulkan bahwa pranayama dalam praktik prenatal yoga memegang peranan penting dalam hal mengendalikan kesadaran diri wanita hamil dalam rangka menghadapi proses melahirkan. Terdapat beberapa teknik pranayama yang baik dipraktikkan selama masa kehamilan yaitu teknik pernapasan diafragma, teknik pernapasan dirgha swasam, sitkari pranayama, sitali pranayama, bhramari pranayama, ujjayi pranayama, dan anuloma viloma pranayama. Napas merupakan jembatan antara calon ibu dan janin, sehingga napas sangat perlu diperhatikan dengan jalan melakukan latihan pranayama dengan berbagai teknik pranayama sesuai dengan kebutuhan wanita hamil.

\section{DAFTAR PUSTAKA}

Aprilia, Y. (2015). Modul Pelatihan: Prenatal Gentle Yoga.

Bara, F. T. (2021). Prenatal Yoga. Jurnal ABDIMAS-HIP: Pengabdian Kepada Masyarakat, 2(1), $1-5$.

Beddoe, A. E., \& Lee, K. A. (2008). Mind-body interventions during pregnancy. Journal of Obstetric, Gynecologic \& Neonatal Nursing, 37(2), 165-175.

Ismayana. (2017). Pengetahuan Ibu Hamil Tentang Perubahan Fisiologis Selama Kehamilan di

Puskesmas Puuwatu Kota Kendari Provinsi Sulawesi Tenggara. Politeknik Kesehatan Kendari.

Kusmiaty dkk. (2009). Perawatan Ibu Hamil. Yogyakarta: Firtamaya.

Madja, I. K. (2018). Fungsi Astangga Yoga Patanjali (Perspektif Pendidikan Agama Hindu). Guna Widya: Jurnal Pendidikan Hindu, 4(1).

Maharani, N. P. R. A. (2020). Pranayama Sebagai Sains Spiritual. Jurnal Yoga dan Kesehatan, 2(2), 110-117.

Mujahidin, A. \& Khoiriyah, Z. F. (2018). Konsep Pendidikan Prenatal dalam Perspektif Tafsir Al-Mishbāh Karya M. Quraish Shihab. TA’ALLUM: Jurnal Pendidikan Islam, 6(1), 121150.

Rafika, R. (2018). Efektifitas Prenatal Yoga terhadap Pengurangan Keluhan Fisik pada Ibu Hamil Trimester III. Jurnal Kesehatan, 9(1), 86-92.

Rahmawati, P. R. (2020). Prana Dan Gaya Hidup: Upaya Meningkatkan Energi Vital Tubuh. Jurnal Yoga dan Kesehatan, 2(1), 12-22.

Resmaniasih, K. (2014). Pengaruh teknik pernapasan diafragma terhadap kecemasan pada ibu hamil trimester III. Program Pascasarjana Undip. 
Rusmita, E. (2015). Pengaruh Senam Hamil Yoga Terhadap Kesiapan Ibu Hamil Menghadapi Persalinan di RSIA Limijati Bandung. Jurnal Ilmu Keperawatan, 3(2), 38-46.

Saraswatī, S. S. P. (2005). Pātañjali Rāja Yoga. Surabaya: Paramita.

Sena, I. G. M. W. (2020). Pranayama Sebagai Praktek dalam Mencegah Virus. Jurnal Yoga dan Kesehatan, 3(1), 1-12.

Sindhu, P. (2009). Yoga Untuk Kehamilan: Sehat, Bahagia \& Penuh Makna. Qanita.

Sophia, S., Septriliyana, N., \& Nuzulmi, A. (2018). Efektivitas Yoga Pranayama Terhadap Penurunan Kecemasan Pada Ibu Hamil Trimester III. Prosiding PIN-LITAMAS 1, 1(1), $432-438$.

Stoppard, M. (2008). Conception pregnancy and birth: ensiklopedia kehamilan. Surabaya: Erlangga.

Wardani, R. P. (2012). Hubungan Antara Usia Kehamilan. Skripsi. Surakarta: UNS-F.Kedokteran Jur.Kedokteran.

Wiadnyana, M. S. (2011). The power of yoga for pregnancy and post-pregnancy. PT Gramedia Pustaka Utama.

Wulandari, S., \& Wantini, N. A. (2021). Efektifitas Happy Prenatal Yoga (Teknik Ujjayi Pranayama dan Nadi Sodhasana) dalam Menurunkan Ketidaknyamanan Fisik Pada Kehamilan Trimester III. Jurnal Kebidanan Indonesia, 12(2), 18-27.

Yeyeh, A. dan R. (2014). Asuhan Kebidanan I (Kehamilan). Jakarta: CV. Trans Info Media.

Zuhrotunida, Z. (2020). Efektifitas Yoga Terhadap Tingkat Kecemasan Ibu Bersalin: Studi Literatur. Jurnal JKFT, 5(2), 75-81.

Yanti, Risna Dewi, \& Ayu, Ni Gusti Made. (2017). Hubungan Antara Pengetahuan Ibu Hamil Tentang Tanda Bahaya Dan Komplikasi Kehamilan dengan Kepatuhan Kunjungan Antenatal dan Pemilihan Tempat Bersalin di Wilayah Tanah Sareal Bogor. Jurnal Ilmiah Kesehatan Diagnosis, 8(1), 98-105.

\section{Sumber Virtual}

https://kbbi.web.id/prenatal, diakses tanggal 19 Juli 2021, 21.28 WITA. 